\title{
ECONOMICS, PUblic POLICY, AND LAW
}

\author{
Susan Rose-Ackerman*
}

\section{Introduction}

Some lawyers view the law as a self-contained body of wisdom independent of the contaminating influences of other branches of knowledge. To them, 'the law', as interpreted by lawyers and judges, should stand above narrow partisan, political concerns and should avoid mixing with the theory and practice of social science. Such lawyers resist efforts to combine law with economics. In doing so they miss an opportunity for gaining a deeper understanding of the way law works in the world.

Economics is method, not ideology. It is based on certain assumptions about human behavior, but it is not inherently right wing or left wing. Despite its association in the United States with the politically conservative professors and judges associated with the University of Chicago, economics can be invoked by commentators anywhere in the political spectrum. It can enrich the arguments of anyone interested in political theory and social policy. ${ }^{1}$

Economic analysis is based on a few fundamental premises. Individuals and business firms are the basic units of analysis. Collective action must be explained, not assumed. Economists take preferences and goals as given and ask how market conditions affect people's efforts to improve their lives. Economists have also begun to ask how non-market institutions such as governments and the legal framework affect individual behaviour.

The fundamental principles of economic reasoning are expressed in the notion of opportunity cost. Resources are scarce, and choices must be made. Every choice closes off other opportunities. Spending money in one way means that it cannot be spent in another. Time used sleeping cannot be spent watching television. Coal that fuels an electric power plant cannot stoke a blast furnace. A rise in the price of a product represents an increase in

* Henry R Luce Professor of Law and Political Science, Yale University, and co-director of the Center for Law, Economics, and Public Policy, Yale Law School.

1 This section of the paper is based on S Rose-Ackerman Rethinking the Progressive Agenda: The Reform of the American Regulatory State (Free Press, New York, 1992) chapters 1 and 2. 
the opportunity cost of using that product. Thus, fewer units will be demanded. Although differences in individual preferences determine how people use their scarce resources and how strongly they react to price changes, people respond to economic incentives. Changes in opportunity costs can change behavior without any change in one's underlying psychology.

Economic incentives include more than just market prices. Most people have no problem accepting the idea that if the price of apples increases, with no change in the quality of apples or of the incomes and preferences of consumers, then the number of apples demanded ought to fall. The extent of the fall depends upon the price of close substitutes (pears) and the intensity of the population's craving for apples, but the direction of movement is clear. What may be more controversial is the claim that other costs can play the same role as market prices in influencing behaviour.

Here is where the economic analysis of law enters. Laws provide a framework within which individuals and organisations operate. Changes in the law change the opportunity costs of various activities and influence behaviour. An increase in the penalty for overtime parking leads more people to feed their parking meters. A strengthening of negligence standards in tort law produces increased caretaking. Tighter environmental regulations induce firms to spend more on pollution control. Restrictive regulations may generate bribes to circumvent the rules. Conversely, changes in the world can change the response to existing laws. An increase in unemployment may increase crime by reducing the value of seeking legal employment. Changes in economic conditions can have systematic impacts on contract terms by shifting the bargaining power of the parties. Thus the impact of law on the world is a function, not only of the law itself, but of the conditions in which it is operating. A law in New Zealand may have a very different impact from an identical law in Sri Lanka.

Economics is not just about prediction. It is also about prescription. Economists emphasise efficient resource allocation, but members of the profession have not settled on a single definition of the term. Two meanings are important in the field of law and economics. First, an efficient society, in Pareto's sense, is one where no one can be made better off without making someone else worse off. There are no free lunches left. There is no way to rearrange the laws and institutions of society to improve the position of some without harming others. A second, more controversial, meaning of efficiency, views a change as efficient if the gainers could compensate the losers. They need not, however, actually do so. Under this standard, the policy analyst or legal reformer seeks policies that maximise the net dollar value of benefits using a method that seeks to monetise intangible and nonmarketed benefits and costs. ${ }^{2}$ The first definition treats all Pareto optimal points as equally

2 For a fuller discussion of cost-benefit analysis see, for example, A A Schmid, Benefit-Cost Analysis: A Political Economy Approach (Westview Press, Boulder CO, 1989). 
efficient. Other non-economic values must be used to choose among them. The second, selects the Pareto efficient point that has the highest value to society using dollars as the unit of measurement. This cost-benefit test selects the point where marginal cost equals marginal benefit for the program under consideration. It is only a well-defined concept for legal reforms that will leave relative prices unchanged. Otherwise policy options may be ranked differently depending upon whether projects are evaluated ex ante or ex post.

\section{Efficiency and Justice}

The economist's concentration on efficiency leads some critics, including some lawyers, to argue that economics is flawed because it is unconcerned with justice. To understand the constructive role that economics can play in legal analysis, one must face that criticism.

First, it is not correct to say that economists are unconcerned with justice. Rather, they recognise that economics, taken by itself, has nothing to say about justice. Any lawyereconomist who makes normative claims about the distribution of income and wealth must have a political philosophy beyond pure economics. Many are committed to utilitarianism. Richard Posner, in contrast, argues for maximising the dollar value of social product. He would elevate the cost-benefit criterion outlined above from a means of evaluating individual projects to an overall political philosophy. ${ }^{3}$ Libertarian thinkers emphasise free contractual choice and corrective justice in the law. ${ }^{4}$ Others are egalitarians who favor a redistribution of resources. Still others emphasise the preservation of individual rights. None of these positions is inconsistent with the core of economic theory, but none is entailed by it either.

Second, economics provides a framework within which discussion of justice can proceed. Economists have demonstrated that if the conditions for a competitive market are satisfied, then the resulting outcome will be Pareto efficient. Similarly, every Pareto efficient outcome can be generated by some initial distribution of resources given competitive conditions. ${ }^{5}$ Thus suppose a nation's legal system has established conditions that further the competitive market. Then the state still has one more task to fulfil. It must set the initial distribution of resources consistent with the nation's view of just starting points. An

3 R Posner The Economics of Justice (Harvard University Press, Cambridge MA, 1983). See the critique by A Kronman "Wealth Maximization" (1980) 9 Journal of Legal Studies 227. Posner ignores the problem of valuation mentioned in the text. He appears to assume that there is an unambiguous set of right prices for valuing alternative distributions.

4 R Epstein Takings; Private Property and the Power of Eminent Domain (Harvard University Press, Cambridge MA, 1985).

5 These two propositions constitute the two fundamental theorems of welfare economics. For an accessible discussion see A M Feldman Welfare Economics and Social Choice Theory (Martinus Nijhoff Pub, Boston, 1980) 39-64. 
egalitarian starting point can produce a Pareto efficient outcome just as well as an inegalitarian one. The actual mixture of goods and services produced and the dollar value of Gross Domestic Product will differ in the two cases, but that is not the essential point. Rather, given any initial distribution, people make mutually beneficial trades and produce a result that is at least as good for all of them as the initial point.

But the sharp distinction between justice and efficiency posited above is obviously too simple and utopian. Every nation begins with some initial distribution so that redistribution itself uses resources and creates inefficiencies. Arnold Harberger used the example of delivering ice cream to people on a desert oasis. ${ }^{6}$ Arthur Okun referred to a leaky bucket. ${ }^{7}$ Economic analysis complements discussions of distributive justice by highlighting tradeoffs between redistribution and efficiency. Enforcing principles of corrective justice can also be expensive. Witness the huge transaction costs being borne by Germany as it seeks to resolve hundreds of thousands of claims to property in the former East Germany. ${ }^{8}$ Economic analysis can help by recommending programmes that reduce the deadweight loss associated with polices based on principles of justice. For example, there is a substantial literature in economics recommending that redistributive programmes be monetised or, at least, converted to vouchers rather than direct in-kind transfers. Another strand of research recommends a negative income tax but criticises the use of the income tax system to provide specialised benefits such as housing subsidies. ${ }^{9}$

Although economics can provide helpful advice about the design of redistributive policies, its central role in legal analysis lies elsewhere. An implicit legal structure undergirds the standard competitive model. Although not explicitly mentioned by those who developed these models, the rule of law lies behind these economic theories. In order for these models to make sense, there must be a skeleton legal system that clarifies and enforces property rights and enforces contracts. Some libertarian economists in their haste to build new societies in the wake of the fall of Communism have forgotten that basic truth. The benefits of the 'free' market are not available without laws that set the ground rules under which market transactions can take place and enforce contracts. Although the range of possible background legal conditions appears to be quite broad, it is not infinite. As the

6 A C Harberger "Three Basic Postulates for Applied Welfare Economics" 9 Journal of Economic Literature 785 (1971).

7 A M Okun Equality and Efficiency, The Big Tradeoff (The Brookings Institution, Washington, DC, 1975).

8 See, J J Doyle "A Bitter Inheritance: East German Real Property and the Supreme Constitutional Court's 'Land Reform' Decision of April 23, 1991" 13 Michigan Journal of International Law 832 (1992).

9 See S Rose-Ackerman (1992), above note 1, chapter 7, 97-117, for a discussion and citations to the relevant literature. 
new states in Eastern Europe are discovering to their dismay, vague, nonexistent, or poorly enforced rules can undermine efforts at economic development as surely as excessive and overly rigid legal strictures. ${ }^{10}$

The overlap between law and economics is not limited to laws that provide a framework for free market trades. Economic analysis is especially important for legal thinking when competitive market conditions cannot be assumed. Perfect competition is a construct of economic theory, not a description of any real society. Market failures provide a justification for state action. Some goods and services, such as national defence, are consumed in common and cannot be allocated efficiently through private markets. In other cases, private production and consumption choices create external costs (or benefits) that cannot practically be handled through the proper assignment of private property rights and individualised bargains. Other markets are affected by imperfect information or heavy entry and exit costs. Sometimes economies of scale are so large that a single producer can supply the market in the most productively efficient way, but may exploit its monopoly power to keep prices high. In all these cases applied economists have made concrete suggestions for the design of public programmes and regulatory statutes. The goal of these proposals is to correct the market failure without introducing other distortions into the economy.

Proposals to move the economy toward the Pareto efficiency frontier generally have distributive consequences as well. In principle, policies exist that can correct market failures consistent with society's distributive goals. In practice, this is not easy. Sometimes the problem is not the technical one of designing effective programs, but involves basic disagreements about what is just. Thus in the United States some argue that the state should compensate people whenever it interferes with the status quo no matter how unjust the status quo seems to others. ${ }^{11}$ In the most extreme version of these proposals, those who obtained windfall gains from using underpriced federal resources would be compensated if the government raises prices to market clearing levels. ${ }^{12}$ Similarly, recent regulatory reform proposals that mandate cost-benefit analysis are viewed as a way "to get the government off the backs of American business." This is a category mistake since cost-benefit analysis

10 See S Rose-Ackerman "Reducing Bribery in the Public Sector" D V Trang (ed) Corruption and Democracy: Political Institutions, Processes and Corruption in Transition States in East-Central Europe and in the former Soviet Union (Institute for Constitutional Policy, Budapest, 1994) 21-28.

11 Epstein (1985) above $\mathrm{n} 4$.

12 See, for example, HR 925 passed by the US House of Representatives on March 3, 1995. Under this proposed statute, if the market value of a person's land falls by $20 \%$ or more as a result of government regulation under certain environmental and natural resource laws, the government would have to pay compensation. An amendment to require the losses to be offset by gains occasioned by federal policies was defeated. B Benenson "House Passes Property Rights Bill" Congressional Quarterly March 4, 1995, 680. 
is a technique for designing effective public programmes, not a means of limiting government. It only becomes one when combined with a strong burden of proof on government in the face of uncertainty and with strengthened possibilities for outside review in the hands of the objects of regulation. Recent proposals conflate demands for good analysis with normative judgments about the role of the state. ${ }^{13}$

\section{Collective Choices}

Just as the study of economics can illuminate the role of law in society, so too can the study of law suggest new problems to economists. It serves as a counterweight to abstract formal modelling and suggests new, more institutionally-based, topics. Basic economic models assume that individuals maximise their utility and firms maximise their profits. The state only enters as a black box that can correct market failures or redistribute resources. But firms are collections of individuals, and the state is a set of institutions full of politicians and bureaucrats with their own goals and desires.

Early on, economic analysts contributed to our understanding of why firms arise and of the control problems faced by large publicly-held private corporations. ${ }^{14}$ Laws regulating modern corporations and security markets reflect both an understanding of the economic function of modern firms and the risks of permitting their unconstrained operation. ${ }^{15}$ Political organisations, public bureaucracies, and courts have only recently engaged the attention of economists. The early postwar period saw a beginning of interest in voting procedures. Drawing on earlier work on majority rule, Kenneth Arrow proved that aggregating individual preference rankings into a consistent social preference ranking was impossible under certain quite general conditions. ${ }^{16}$ In retrospect, it seems amazing that anyone could have thought that a social ordering analogous to individual orderings would be possible in a democracy with heterogeneous tastes. Such, however, was the optimism of postwar economists equipped with their new mathematical tools that anything seemed possible. Arrow's work, as extended by others, demonstrated decisively that even in a direct democracy where everyone votes, collective choice is likely to be a difficult and contested exercise. Majority rule, a broadly accepted method of choice, has deep problems when issues are multifaceted and people disagree, but no reasonable rule is immune from

13 See "In Regulatory Overhaul Debate, Every Word Counts" New York Times July 10, 1995.

14 R Coase "The Nature of the Firm" (1937) 4 Economica (ns) 386; A A Berle and G C Means The Modern Corporation and Private Property (The Macmillian Company, New York, 1932).

15 For an introduction to this work prepared for a legal audience see R Romano (ed) Foundations of Corporate Law (Oxford University Press, New York, 1993).

16 K J Arrow Social Choice and Individual Values (Yale University Press, New Haven, 1951). 
strategic manipulation. ${ }^{17}$ Avoiding political choices and relying on the market is hardly an answer to the difficulty of locating fair voting rules. Market outcomes build on the existing distribution of wealth and power and thus also represent implicit choices about distributive justice. The resulting outcomes may be no more satisfactory than self-conscious political choices. The market serves a valuable function, given an acceptable distribution of wealth and competitive conditions. If those conditions are not met, imperfect collective choice processes cannot be avoided.

But the problem of collective choice is deeper than the difficulties isolated by Arrow and his followers for direct democratic choice. Modern democracies are representative systems. The preferences of the public are not necessarily well-reflected in the choices of the legislature. One of the fundamental insights of economics was to point out that individuals with identical interests might fail to organise to further these interests. The communal nature of many political benefits might lead each individual to free ride off the efforts of others. As a consequence, no one might take action. Small groups with common interests may organise more easily than large groups, and elected politicians with hopes for higher office may become political entrepreneurs, but the interests that manage to organise may be a biased sample of the range of opinion in a democracy. ${ }^{18}$ Thus this research cast doubt on the strong claims for pluralistic democracy and suggested that the statutes passed by the legislature were likely to represent a biased sample of citizen interests. ${ }^{19}$ This skepticism about the product of the legislative process complemented the libertarian biases of some law and economics scholars to produce an argument for deregulation and a reliance on the common law. Although their critiques often have merit in particular cases both with respect to substance and politics, the general pessimism about democratic government expressed by these scholars is only justified if one has great faith in the normative value of free market trades and the decisions of common law judges. ${ }^{20}$ Such faith seems to me difficult to justify. The libertarian branch of law and economics has a one-sided view of the sources of institutional failure. All institutions are imperfect, and the task for a more balanced law and economics enterprise is to locate reasonable reform strategies.

17 The recent literature is reviewed in D C Mueller Public Choice II (Cambridge University Press, Cambridge, 1989).

18 The classic work is M Olson, Jr The Logic of Collective Action; Public Goods and the Theory of Groups (Harvard University Press, Cambridge MA, 1965).

19 The work of J Buchanan and his co-authors represents a particularly strong version of this position. See, for example, G M Brennan and J Buchanan The Power to Tax: Analytical Foundations of Fiscal Constitution (Cambridge University Press, Cambridge, 1980).

20 See, for example, F Easterbrook "The Supreme Court 1983 Term: Foreword: The Court and the Economic System" (1984) 98 Harvard L Rev 4; W M Landes and R A Posner The Economic Structure of Tort Law (Harvard University Press, Cambridge, MA, 1987); R A Posner Economic Analysis of Law 3 ed, (Little, Brown, Boston, 1986). 
The difficulty of designing well-functioning representative institutions is, however, only one part of the organisational challenges facing the modern state. Modern democracies are not only representative, they are also complicated. They have large bureaucracies to carry out their public programmes. Although some programmes can be handed over to private firms and others can simply be eliminated, a core of government programmes will remain. Some can be justified by economic analysts as devices to correct market failures. Others may redistribute benefits to the worthy, and still others may only provide benefits to special interests. Whatever a programme's underlying purpose, it must be administered. The need to delegate to the bureaucracy and to control that delegation is one of the recurring puzzles that democracies must resolve. Law and economics scholars, joined by others in political science and administrative law, have begun to make progress in analysing this difficult problem.

Consider the example of environmental policy. Market failures exist that justify state action. Air and water pollution cross property lines and cannot feasibly be controlled by rearranging private property rights and allowing private tort suits. ${ }^{21}$ Instead, statutory regulation is needed. Economic analysis has suggested ways to design public programmes that permit cost effective regulatory strategies. At the top of economists' lists are programmes that replace command and control regulations with pricing systems that give pollution dischargers an incentive to cut back in a least cost way. The literature on effluent charges, tradeable pollution rights, and other incentive schemes is broad and deep. ${ }^{22}$ Until recently, however, it was generally ignored by politicians and policy makers. In the last few years in the United States that has begun to change, and now economists face a new challenge: converting their ideas into workable schemes. ${ }^{23}$

\section{Design of Regulatory Structures}

Most of the scholarly work on the design of efficient regulatory schemes has been done by policy oriented economists. Lawyer-economists in the United States have played the role of salesmen, bent on persuading the legal and political establishment of the value of

21 S Rose-Ackerman "Environmental Liability Law" in T H Tietenberg (ed) Innovation in Environmental Policy: Economic and Legal Aspects of Recent Developments in Environmental Enforcement and Liability (E Elgar, Hants, UK, Brookfield, VT, USA, 1992) 223-243.

22 For an introduction see T H Tietenberg "Economic Instruments for Environmental Regulation" in D Helm (ed) Economic Policy Towards the Environment (Blackwell, Oxford, UK; Cambridge, USA, 1991) 86-110.

23 The 1990 Amendments to the US Clean Air Act established a system of tradeable pollution permits for sulfur dioxide emissions from power plants [CAA §§401-413]. For a discussion of the experimental Regional Clean Air Incentives Market being developed in the Los Angeles basin see D A Carlson and A M Scholtz "RECLAIM: Lessons from Southern California for Environmental Markets" Environmental Law and Practice January/February 1994 15-26. 
experimenting with more cost-effective systems. But there is also a more genuinely interdisciplinary role for lawyer-economists interested in administrative law in democratic states. They can contribute to the ongoing discussion over reconciling technocratic knowledge with the concerns of ordinary citizens. Modern states should develop principles of administrative practice that match substance with procedure. The political nature of policy problems should govern the design of bureaucratic structures. The central tension is between competence and legitimacy. If we are not content to define competence as providing legitimacy, or legitimacy as meaning competence, policy makers must face the potential for conflict. Much past discussion has, however, exaggerated the conflict. Fundamental difficulties arise, not so much from the democracy-technocracy tradeoff itself as from a mismatch of techniques and tasks. Table 1 provides a simple schematic representation of good matchups. ${ }^{24}$

Table 1

\begin{tabular}{|c|c|c|c|c|c|}
\hline \multirow[b]{3}{*}{ SUBSTANCE } & \multicolumn{5}{|c|}{$\overline{\overline{\text { PROCESS }}}$} \\
\hline & \multirow{2}{*}{$\begin{array}{c}\text { A } \\
\text { Scientific } \\
\text { Method }\end{array}$} & \multicolumn{3}{|c|}{$\begin{array}{c}\text { B } \\
\text { Bureaucrat-led } \\
\end{array}$} & \multirow{2}{*}{$\begin{array}{c}\text { C } \\
\text { Consensual }\end{array}$} \\
\hline & & $\begin{array}{c}1 \\
\text { Courtlike }\end{array}$ & $\begin{array}{c}2 \\
\text { Quasi-legislative }\end{array}$ & $\begin{array}{c}3 \\
\text { Administrative } \\
\text { Balancing }\end{array}$ & \\
\hline A Technical & $x$ & & & & \\
\hline B Individual Rights & & $x$ & & & \\
\hline $\begin{array}{ll}\text { C } & \text { Political } \\
& 1 \quad \text { Distributive }\end{array}$ & & & $x$ & & \\
\hline $\begin{array}{cr}2 & \begin{array}{l}\text { Net benefits possible } \\
\text { a }\end{array} \\
& \text { All interests not } \\
\text { well-represented }\end{array}$ & & & & $x$ & \\
\hline $\begin{array}{lll}\mathrm{b} & \begin{array}{l}\text { All interests well- } \\
\text { represented }\end{array}\end{array}$ & & & & & $x$ \\
\hline
\end{tabular}

The upper left-hand side of the table matches purely scientific or technical questions [row A] with evaluation methods using the canons of the relevant science [col. A]. The goal is to establish scientific validity, not to promote fairness or democratic legitimacy. Peer review is the evaluative method accepted within the scientific community. Bias is limited by such devices as using independent reviewers, giving greater credence to replicated results,

24 The following section of the paper is derived from S Rose-Ackerman Controlling Environmental Policy: The Limits of Public Law in Germany and the United States (Yale University Press, New Haven, 1995) 120-125. 
and preparing written evaluations. ${ }^{25}$ The reviewers' identities may be kept secret from the researchers so that they can respond only to the criticisms and not the critics. Judicialised procedures are not used.

Of course, such conventional processes may overlook truly innovative or unusual approaches, but that is the price of assuring a basic level of competence. The aim of the administrative process is not to advance science but to provide a sound background for regulation. ${ }^{26}$ The ideal is a balanced assessment of existing research that points to strengths and weaknesses in theory and in empirical testing and that isolates those areas of uncertainty most relevant to the ultimate policy choice. Nevertheless, although scientific norms guide the evaluative process, the choice of topics remains a policy question that must be determined by politically responsible authorities.

The protection of individual rights [row B] requires a quite different procedural framework [col B.1]. The aim of a courtlike process is a fair decision that permits individuals to defend themselves against arbitrary state authority. Under one familiar view of such procedures, individuals have a right to a hearing and must be able to discover the basis of the bureaucracy's decision. They must be able to challenge the state's decisions as unfair or illegal before independent bodies, such as courts. Although the content of rights and the details of the required procedures are controversial issues, the individualized nature of the proceeding is not in doubt. Procedures derived from civil and criminal trials frequently form the basis for such proceedings within the executive. Their purpose is to protect individual rights; they are poorly designed for resolving policy issues.

Environmental statutes frequently delegate political tasks to the bureaucracy. A bureaucracy cannot use majority voting; it must find other means to make choices. Neither scientific nor judicialised procedures are appropriate. The bureaucracy's job is to balance conflicting interests, not to discover scientific truths or to preserve rights. Science and technology provide a background to many political disputes, and the preservation of individual rights is always a constraint on policy. Nevertheless, neither peer review nor judicial procedures provide a helpful framework for policy decisions that involve conflicts of values and interests.

25 Compare Daubert v Merrell Dow Pharmaceuticals 113 SCt 2786 (1993) at 2795-2797, which makes some "general observations" about the admissibility of scientific evidence into trials. The US Supreme Court argues that judges should ask if the theory has been empirically tested and subjected to peer review. They should consider the margin of error in the results and whether the result is "generally acceptable".

26 Compare the similar sentiment in Daubert at 2798, which contrasts the quest for truth in the courtroom and with that in the laboratory. The Federal Rules of Evidence are "designed not for the exhaustive search for cosmic understanding but for the particularised resolution of legal disputes". 
Table 1 distinguishes three types of political choices faced by bureaucratic policy makers. In the easy case [row C.2.b], everyone can come out ahead, and all interests have strong and equally balanced representation. In such win-win cases, consensual or "participant-led" processes [col C] seem appropriate. ${ }^{27}$ The participants will disagree about the division of the gains, but a negotiation designed to produce a unanimous decision is, in principle, possible. The bureaucracy can play the role of facilitator. It can structure the process, clarify the consequences of failure, and select the participants. Given these background conditions, the state could simply accept the policy agreed on by the participants and promulgate it as a rule or guideline. Although the range of outcomes is determined by the statutory framework, the actual outcome is the result of negotiation. Publicity and reasoned decision-making are unimportant. If everyone agrees, the outcome is, by definition, legitimate.

The easy case seldom describes the reality of political choices delegated to the bureaucracy. When it does not, the process must be "bureaucrat-led", with public officials trading off interests and values. There are no objectively right answers. A decision's acceptability is a function of an individual's political philosophy and personal stake in the issue. For distributive choices [row C.1], bargaining will never produce a consensus. Instead, bureaucrats should make the choice in a self-conscious way that balances the conflicting interests but does not require everyone to approve of the outcome [col B.2]. The administration should articulate the mixture of principle and political expediency that produced the choice.

In many situations, mutually beneficial solutions exist, but they cannot be reached through negotiation [row C.2.a]. Most environmental problems, for example, arise from failures of the market system and so could be solved with net gains for all. Nevertheless, most are not suitable for regulatory negotiation. The problems of group representation are intractable because some of those concerned are members of extremely diffuse groups, such as consumers of manufactured goods or breathers of the air. ${ }^{28}$ Thus, the public authorities must make the ultimate decision. They should hear representatives of those affected and then apply policy analytic tools to reach a decision. I label this approach "administrative balancing" [col B.3].

Even if each group prefers the new policy to the status quo, everyone may be unhappy with his or her share of the gains. Further, although ordinary citizens may prefer policies

27 The exceptions concern cases where citizens believe that costs should be imposed on one group. For example, if voters believe that firms should end up with lower profits when occupational health and safety are controlled, a labour-management negotiation that sets the status quo as a benchmark would be politically unacceptable.

28 For a critical view of regulatory negotiation in the environmental context see $\mathrm{S}$ Rose-Ackerman (1995), above note $24,102-106$. 
that impose costs on polluters, dischargers will support subsidies and tax concessions. Because of conflicts over the distribution of gains, the government must justify its decision to the public and the business community. The aim is not to make everyone happy. Democratic government implies the existence of minority parties and defeated politicians. Instead, the authorities must show that the outcome is consistent with the legislative purpose. For example, an air or water pollution policy designed to correct a market failure could be carried out using principles of cost-benefit analysis. A policy designed to site waste disposal facilities could be implemented under egalitarian principles of distributive justice. The explanation must both articulate the goals behind the policy and clarify the link between the available information and the outcome.

Because direct oversight by the legislature is generally insufficient, the authorities must use legitimate procedures to produce a decision. In particular, administrative procedures should permit experts, ordinary people, and organised groups to present their information and views. This implies broad public notice, an openness to information and opinions from diverse sources, and a willingness to share this material with those interested in the outcome. But openness is not sufficient. I have postulated that groups are not equally well represented, which means that the bureaucracy must gather data and opinions itself.

Bureaucrats have incentives to avoid the bother of publicly accountable processes and may favour organised groups with a high stake in the outcome. Thus, judicial review should be available. This review would recognize the superior expertise of agencies vis-à-vis the courts as well as acknowledge agencies' incentives to deviate from competent and democratically legitimate procedures. The courts would review procedures by requiring officials to listen to a wide range of facts and opinions and to explain their decisions. Bureaucratic choices are acceptable, not because they satisfy everyone, but because the process assures that no major bodies of knowledge and opinion have been ignored. ${ }^{29}$

My outline of the ideal matches of procedure and substance is, however, too simple. Not all cases fit cleanly into one box or another. The hard cases involve both science and politics, where hybrid procedures are sometimes possible. Negotiations that resolve preliminary issues could be followed by a bureaucratic choice, or conversely, preliminary technocratic fact-finding could be followed by negotiation in the light of this information. ${ }^{30}$ Scientists, engineers, and social scientists would assess the quality of research and technical information. This material could then form the basis for policy makers to

29 R Stewart "The Reformation of American Administrative Law" (1975) 88 Harvard L Rev 1667. The informal rulemaking provisions of the US Administrative Procedures Act incorporate these principles [APA §553].

30 Such hybrids, however, raise their own problems. The incentives to negotiate are changed when the outcome is an input to the second stage. The objectivity of information presented at the firststage hearing may be influenced by its use as an input in a subsequent consensual process. 
ascertain "the state of the art", locate thresholds where human health is "protected", or trade-off human lives against economic prosperity. Such choices are not scientific, or even social-scientific, judgements. They are at the heart of the policy-making enterprise.

Often, however, it is impossible to evaluate the technical data first and then use it to make a policy decision. When this happens, how should the administration proceed? Should it emphasise competence through the use of scientifically acceptable methods, or should it develop a politically legitimate procedure? For bureaucrat-led processes there is often no need to make a choice. Procedures can be designed to further both goals. If hearings provide information, there is no inconsistency between them and the subsequent technocratic exercise used to generate a final rule or standard. If democratic legitimacy requires a statement of reasons, so, too, do scientific canons.

Conflicts will continue to exist, but they are disputes over values and administrative competence, not over process. Suppose, for example, that officials, operating under an openended statute, believe that cost-benefit or risk-assessment techniques are the best way to balance interests. In public hearings, individuals provide information and explain how they will be affected by the policy. Some individuals, however, question the agency's methodology and go on to challenge the ultimate decision in court. Such disputes indicate the lack of a political consensus over how to make competent policy. Challengers may don the mantle of democratic legitimacy in criticising the agency's decision, but their fundamental complaint is over policy, not procedure. If everyone agreed on a single balancing technique, it is hard to see how anyone could object in principle to an open and accountable process.

The remaining conflicts would be prudential ones over the cost in time and money of extensive procedures and over bureaucratic capacity. Outsiders may claim that the agency is failing because of laziness, stupidity, or venality. The issue for judicial review would be the agency's failure to live up to legislatively mandated standards. Such cases can produce sharp conflicts between public agencies and outside groups, but they are not conflicts between technocratic decision-making and democracy.

In short, for bureaucrat-led processes, the conflicts between competence and democratic legitimacy appear to be less prevalent than some commentators would have us believe. The apparent conflicts that we observe are frequently the result of disputes over substantive standards and over the way public officials fulfil their duties given a view of proper behaviour. If the democratic legitimacy of the administrative process can be improved with no major sacrifice in terms of substantive policy, we can focus on reforms that further these joint goals. We can concentrate on the design of administrative procedures that match the problem to be solved. 


\section{Comparative Law Context}

This framework for analysing the administrative process could be applied in a comparative law context. The study of executive branch policy making in different political systems is a fruitful and understudied area for research. As an example of the kind of work that is possible, I have just completed a study of administrative law and environmental policy making in the United States and Germany. ${ }^{31}$ The project was not an easy one to carry through. It involved language study, a year living abroad, numerous interviews, and many hours with difficult German legal texts. As a result, however, I both came to a deeper understanding of the American administrative law system and gained a richer view of the institutional and legal possibilities available to democracies. Nevertheless, I ended up quite critical of high-level executive branch policy making in Germany. I argued that it is not sufficiently accountable to the public and not sufficiently open to outside sources of expertise. I recommended that some aspects of the American system, in particular, legally enforceable rights to present information to regulatory agencies and written justifications for rules, could usefully be adopted by the German system without violating its democratic structure.

Similar studies could compare these systems with the different cases of the Commonwealth countries and of countries in Europe and the developing world influenced by French legal models. Previous work, mostly by political scientists, has seldom emphasised the distinctive features of administrative law in different systems. They stress the obviously important dimension of political structure and interest group organisation, but do little to analyse either administrative procedures or the efficacy of substantive policy. ${ }^{32}$ New Zealand, as it moves to a new voting system while at the same time attempting to deregulate and rationalise state activity, could provide an instructive laboratory for study especially in comparison both with less dynamic members of the Commonwealth and with non-parliamentary systems such as the United States.

31 S Rose-Ackerman (1995), above note 24.

32 Among the best of the published studies in the environmental and health and safety areas are: $R$ Brickman et al Controlling Chemicals: The Politics of Regulation in Europe and the United States (Cornell University Press, Ithaca, 1985); D Nelkin and M Pollak The Atom Besieged: extra parliamentary dissent in France and Germany (MIT Press, Cambridge MA, 1981); A Peacock, ed The Regulation Game: How British and West German Companies Bargain with Government (Basil Blackwell, Oxford, UK; New York, NY, USA, 1984). Two unpublished doctoral dissertations are especially interesting: M S Greve "Environmentalism and the Rule of Law: Administrative Law and Movement Politics in West Germany and the United States, Ph D dissertation, Department of Political Science, Cornell University, 1987, and M S R Palmer "Constitutional Design and Law: The Political Economy of Cabinet and Congressional Government" JSD Dissertation, Yale Law School, 1994. 


\section{Conclusion}

The intersection between the common law and economic analysis is widely accepted as an object of study in American law schools. As even its critics recognise, those who believe that the law should serve goals other than efficiency need to assess the efficiency costs of alternative rules. However, lawyers with a strong faith in the common law need to face its weaknesses in resolving difficult policy issues such as the safety of products, the cleanliness of the atmosphere, and the quality of medical care. An economic analysis of the common law suggests that it cannot be an all-purpose resolver of the problems of the modern capitalist welfare state. Lawyer-economists must study, not only substantive legal problems, such as environmental protection, but also procedural and institutional questions. Law and economics must be joined by political science, and perhaps by public administration as well. The intersection of substance (control of accidents), institutional structure (common law courts), and procedure (the case method and the role of precedent) that has proved so fruitful for the study of the common law ought now be extended to the study of government. The range of subjects is broader, and the institutional structure and procedures are more complex and varied, but the ultimate promise is the same. The goal is to link programmatic concerns to institutional frameworks to produce results that are both substantively justifiable and democratically legitimate. 